\title{
PERTUMBUHAN DAN PRODUKSI TANAMAN TUMPANGSARI CABAI DENGAN BAWANG MERAH MELALUI PENGATURAN JARAK TANAM DAN PEMUPUKAN NPK PADA TANAH GAMBUT
}

\author{
Growth and Production of Tumpangsari Chili Plants \\ with Red Onion Through and NPK Fertilization in Peat
}

\author{
Raisa Baharuddin dan Selvia Sutriana \\ Program Studi Agroteknologi, Fakultas Pertanian Islam Riau \\ Jl. Kaharuddin Nasution No. 113 Pekanbaru.28284. Telp: 0761-674681; Fax: 0761-674681 \\ Email korespodensi: raisabaharuddin@agr.uir.ac.id
}

\begin{abstract}
The increased productivity of peatlands can be done by applying an intercropping system. The commodities that can be intercropped are chili and shallots. This research aims to determine the planting distance and dosage of NPK fertilization on production in intercropping of chili and shallot on peat soil. This research was conducted from August to December 2018 at the Experimental Farm, Faculty of Agriculture, and Islamic University of Riau. Research experiments used a completely randomized design with three replications. The first factor of the spacing consisted of 4 levels, J1 (50 x $50 \mathrm{~cm}), \mathrm{J} 2(60 \times 50 \mathrm{~cm}), \mathrm{J} 3(70 \times 50 \mathrm{~cm})$. The second factor of NPK 16:16:16 fertilizer dosage were N0 (0 kg. ha-1), N1 (250 kg. ha-1), N2 (500 kg. ha-1), N3 (750 kg. ha-1). Shallot was planted 2 weeks before planting chili with a spacing of $20 \mathrm{~cm} \times 20 \mathrm{~cm}$. The results indicated that the best planting distance and dosage of NPK on intercropping chilli pepperand shallots in peat land was $50 \times 50 \mathrm{~cm}$ and NPK $500 \mathrm{~kg} / \mathrm{ha}$ for growth and production of shallots. The best planting distance and dosage of NPK on intercropping chilli pepper and shallots in peat land was $50 \times 50 \mathrm{~cm}$ and NPK $750 \mathrm{~kg} / \mathrm{ha}$ for production of chilli pepper.
\end{abstract}

Keywords: Planting Distance, NPK Fertilizer, Peat, Intercropping

\begin{abstract}
ABSTRAK
Peningkatan produktivitas lahan gambut dapat dilakukan dengan menerapkan sistem tumpang sari. Beberapa komoditas yang dapat dilakukan sistem tumpangsari yaitu cabai merah dan bawang merah. Tujuan penelitian ini adalah untuk menentukan jarak tanam dan dosis pemupukan NPK yang tepat pada tumpangsari cabai merah dan bawang merah di tanah gambut. Penelitian ini dilaksanakan di Kebun Percobaan Fakultas Pertanian Universitas Islam Riau Pekanbaru. Penelitian berlangsung dari bulan Agustus hingga Desember 2018. Penelitian dilaksanakan dengan menggunakan Rancangan Acak Kelompok (RAK) faktorial dengan 3 ulangan. Faktor pertama jarak tanam terdiri dari 4 taraf yaitu J1 $(50$ x $50 \mathrm{~cm}), \mathrm{J} 2(60 \times 50 \mathrm{~cm}), \mathrm{J} 3(70 \times 50 \mathrm{~cm})$. Faktor kedua dosis pupuk NPK 16:16:16 yaitu N0 (0 kg/ha), N1 (250 kg/ha), N2 (500 kg/ha), N3 (750 kg/ha). Hasil penelitian menunjukkan bahwa perlakuan jarak tanam $50 \mathrm{~cm}$ x $50 \mathrm{~cm}$ dan pupuk NPK $500 \mathrm{~kg} / \mathrm{ha}$ dalam system tumpangsari cabai dengan bawang merah di tanah gambut memberikan pertumbuhan dan hasil tanaman bawang merah terbaik. Perlakuan jarak tanam $50 \mathrm{~cm}$ x $50 \mathrm{~cm}$ dengan pupuk NPK $250 \mathrm{~kg} / \mathrm{ha}$ mememberikan produksi buah tanaman cabai merah terbaik.
\end{abstract}

Kata kunci: Jarak Tanam, Pupuk NPK, Gambut, Tumpang Sari 


\section{PENDAHULUAN}

Upaya pengembangan tanaman hortikultura di lahan gambut masih minim. Hal ini dikarenakan luas lahan gambut yang berpotensi digunakan sebagai lahan pertanian khususnya tanaman sayuran masih rendah. Berdasarkan beberapa hasil penelitian, produksi tanaman sayuran yang dibudidayakan di lahan gambut masih rendah. Penerapan sistem tumpang sari (intercropping) diharapkan dapat meningkatkan produktivitas lahan gambut. Sistem tumpangsari adalah sistem tanam yang terdapat dua atau lebih jenis tanaman yang berbeda ditanam secara bersamaan pada waktu yang sama atau berbeda dengan jarak tanam teratur pada sebidang tanah yang sama (Ratri, dkk, 2015). Menurut Jumin (2010), tumpangsari ditujukan untuk memanfaatkan lingkungan (hara, air dan sinar matahari) dengan sebaik-baiknya sehingga diperoleh produksi maksimal.

Sistem tumpangsari umumnya lebih menguntungkan dibanding sistem monokultur karena produktivitas lahan menjadi lebih tinggi, jenis komoditas yang dihasilkan beragam, hemat dalam pemakaian sarana produksi dan resiko kegagalan dapat diperkecil (Turmudi, 2002). Tumpangsari dapat dilakukan antara tanaman semusim dengan tanaman semusin lain yang saling menguntungkan. Beberapa komoditas hortikultura yang memiliki nilai jual tinggi dan dapat dilakukan sistem tumpangsari yaitu cabai merah dan bawang merah. Bawang merah ditanam sebagai tanaman sisipan antar barisan tanaman cabai merah.

Namun yang menjadi permasalahan dalam sistem tumpangsari adalah kompetisi antar tanaman yang dibudidayakan misalnya terhadap unsur hara, air, nutrisi, cahaya dan ruang tumbuh yang lebih tinggi daripada monokultur (Mauidzotussyarifah, dkk 2018). Kompetisi tersebut terjadi antara tanaman yang sejenis dan berbeda jenis. Oleh karena itu, perlu pengaturan jarak tanam sehingga mengurangi kompetisi antar tanaman tersebut.

Sistem penanaman secara tumpang sari antara bawang merah dan cabai merah merupakan alternatif teknologi yang dapat dikembangkan pada tanah gambut. Pengaturan jarak tanam yang tepat akan mengoptimalkan pertumbuhan dan perkembangan tanaman. Namun permasalahan lain dalam pengelolaan tanah gambut sebagai media tanam yaitu kurangnya atau miskinnya unsur hara pada tanah gambut. Tanah gambut umumnya memiliki kadar $\mathrm{pH}$ rendah, kapasitas tukar kation tinggi, kejenuhan basa rendah, memiliki kandungan unsur $\mathrm{K}, \mathrm{Ca}, \mathrm{Mg}, \mathrm{P}$ yang rendah dan juga memiliki kandungan unsur mikro (seperti $\mathrm{Cu}$, Zn, Mn serta B) yang rendah (Sasli, 2011). Keadaan ini mengakibatkan lahan bersifat miskin hara dan sangat masam. Sehingga perlu penambahan unsur hara pada tanah gambut, yang dapat meningkatkan pertumbuhan dan perkembangan tanaman. Penambahan unsur hara dilakukan dengan menambahkan unsur hara $\mathrm{N}$, $\mathrm{P}$, dan $\mathrm{K}$ dengan pemberian pupuk NPK majemuk. Kebutuhan tanaman akan hara N, P, dan $\mathrm{K}$ tergantung pada jenis tanaman, pola penanaman, populasi dan periode umur tanaman.

Tujuan penelitian ini adalah untuk menentukan jarak tanam dan dosis pemupukan NPK yang tepat pada tumpangsari cabai merah dan bawang merah di tanah gambut.

\section{METODE PENELITIAN}

Penelitian ini dilaksanakan di Kebun Percobaan Fakultas Pertanian Universitas Islam Riau Pekanbaru. Penelitian berlangsung dari bulan Agustus sampai Desember 2018. Bahan tanam yang digunakan dalam penelitian ini adalah benih bawang merah varietas Jawa Bima Brebes dan benih cabai merah varietas Lado F1. Bahan lainnya seperti kompos, pupuk NPK, dolomite, insektisida, fungisida, furadan . Selain itu adapun alat yang digunakan dalam penelitian ini adalah cangkul, meteran, plat perlakuan, cat minyak, paku, handsprayer, gembor, kamera, dan alat-alat tulis.

Penelitian ini menggunakan Rancangan Acak Kelompok (RAK) faktorial dengan 3 ulangan. Faktor pertama jarak tanam terdiri dari 4 taraf yaitu J1 $(50 \times 50 \mathrm{~cm}), \mathrm{J} 2(60 \times 50 \mathrm{~cm}), \mathrm{J} 3$ $(70 \times 50 \mathrm{~cm})$. Faktor kedua dosis pupuk NPK 16:16:16 yaitu N0 (0 kg/ha), N1 (250 kg/ha), N2 (500 kg/ha), N3 (750 kg/ha).

Pengukuran $\mathrm{pH}$ awal dilakukan pada tanah gambut kemudian dilakukan pemberian dolomit dengan dosis 1 ton/ha dan pupuk kompos 15 ton/ha. Tanaman bawang merah ditanam

2 minggu sebelum penanaman cabai merah serta dilakukan pemupukan NPK dengan dosis $350 \mathrm{~kg} / \mathrm{ha}$. Bawang merah ditanam diantara 
tanaman cabai merah dengan jarak tanam $20 \mathrm{~cm}$ x $20 \mathrm{~cm}$. Penyulaman dilakukan pada 1 MST.

Penanaman cabai dilakukan saat bibit berumur 3 minggu. Pemupukan NPK dilakukan 3 tahap, yaitu saat tanam, 21 HST, dan 50 HST dengan masing-masing $1 / 3$ dosis setiap pemberian. Pemanenan bawang merah dilakukan pada umur 60 HST, dimana tanaman telah menunjukkan kriteria panen.

Parameter yang diamati pada tanaman bawah merah yaitu: tinggi tanaman, bobot basah per rumpun dan bobot kering per rumpun. Sedangkan parameter untuk tanaman cabai merah yaitu: tinggi tanaman, jumlah buah, dan bobot buah per tanaman. Data yang diperoleh dianalisis menggunakan analisis ragam (uji F) pada taraf 5\% dengan uji lanjut BNT.

\section{HASIL DAN PEMBAHASAN}

\section{A. Pertumbuhan dan Produksi Tanaman Bawang Merah \\ 1. Tinggi Tanaman}

Hasil analisis sidik ragam menunjukkan bahwa pengaturan jarak tanam dan pupuk NPK berpengaruh nyata terhadap tinggi tanaman bawang merah. Rata-rata nilai peubah yang diamati setelah diuji dengan BNT 0,05 dapat dilihat pada Tabel 1.

Tabel 1. Rata-rata tinggi tanaman bawang merah pada umur 8 MST pada perlakuan jarak tanam dan pupuk NPK dalam sistem tumpangsari cabai dengan bawang merah di tanah gambut

\begin{tabular}{ccccc}
\hline & \multicolumn{4}{c}{ Pupuk NPK } \\
\cline { 2 - 5 } Jarak Tanam & $\begin{array}{c}\text { N0 } \\
(0 \mathrm{~kg} / \mathrm{ha})\end{array}$ & $\begin{array}{c}\mathrm{N} 1 \\
(250 \mathrm{~kg} / \mathrm{ha})\end{array}$ & $\begin{array}{c}\mathrm{N} 2 \\
(500 \mathrm{~kg} / \mathrm{ha})\end{array}$ & $\begin{array}{c}\text { N3 } \\
(750 \mathrm{~kg} / \mathrm{ha})\end{array}$ \\
\hline $\mathrm{J} 1(50 \mathrm{~cm} \times 50 \mathrm{~cm})$ & $30.78 \mathrm{ab}$ & $29.89 \mathrm{abc}$ & $34.56 \mathrm{a}$ & $32.11 \mathrm{ab}$ \\
$\mathrm{J} 2(60 \mathrm{~cm} \times 50 \mathrm{~cm})$ & $28.67 \mathrm{bc}$ & $31.44 \mathrm{ab}$ & $25.78 \mathrm{c}$ & $29.11 \mathrm{bc}$ \\
$\mathrm{J} 3(70 \mathrm{~cm} \times 50 \mathrm{~cm})$ & $29.89 \mathrm{abc}$ & $27.89 \mathrm{bc}$ & $28.78 \mathrm{bc}$ & $34.33 \mathrm{ab}$ \\
\hline
\end{tabular}

$\mathrm{KK}=8.94 \%$

BNT $5 \%=4.78$

Angka yang diikuti huruf yang sama pada baris dan kolom tidak berbeda nyata berdasarkan uji BNT $(\alpha=0.05)$.

Tabel 1 menunjukkan bahwa perlakuan jarak tanam rapat $(50 \mathrm{~cm} \times 50 \mathrm{~cm})$ dengan atau tanpa pemupukan NPK nyata meningkatkan tinggi tanaman bawang merah pada sistem tumpangsari. Semakin lebar jarak tanam cabai yang digunakan dalam system tumpangsari cabai dengan bawang merah, maka tinggi tanaman cenderung menjadi lebih rendah. Hal ini diduga karena jarak tanam yang lebih lebar memiliki ruang terbuka antara tanaman yang lebih luas, sehingga menyebabkan tingginya evaporasi dan leaching unsur hara yang diberikan. Pada tanah marginal dianjurkan menggunakan jarak tanam yang rapat dalam batas tertentu. Hal ini didukung oleh pendapat Noor (1996) bahwa, pada tanah yang kurang subur jarak tanam yang digunakan cenderung lebih rapat. Didukung oleh penelitian Maulidi dan Mustamir (2012) pada tanaman nenas di lahan gambut, bahwa penyerapan unsur hara lebih efisien pada jarak tanam yang rapat.

Bawang merah ditanam 2 minggu lebih cepat dari cabai merah. Hal ini bertujuan untuk mengurangi persaingan antara tanaman dalam sistem tumpang sari dalam memperebutkan unsur hara, air, cahaya dan $\mathrm{O}_{2}$. Tinggi tanaman bawang merah dari hasil penelitian (25.78-34.56 $\mathrm{cm}$ ) masih sesuai dari deskripsi tanaman bawang merah yaitu $25-44 \mathrm{~cm}$. Hal ini menunjukkan bahwa bawang varietas Bima Brebes mampu tumbuh dan beradaptasi pada tanah gambut. Hal ini sependapat dengan penelitian Pubiarti (2012), Sutriana dan Baharuddin (2019) yang menyatakan bahwa tanaman bawang merah varietas Bima Brebes cukup adaptif terhadap tanah gambut.

\section{Jumlah umbi per rumpun}

Hasil analisis ragam menunjukkan bahwa perlakuan utama pupuk NPK memberikan pengaruh nyata terhadap jumlah umbi per rumpun tanaman bawang merah (Gambar 1). Gambar 1 menunjukkan bahwa jumlah umbi per rumpun bawang merah nyata meningkat dengan perlakuan pupuk NPK dosis $250-750 \mathrm{~kg} / \mathrm{ha}$. Hal ini menunjukkan bahwa dengan pemberian pupuk NPK yang dilakukan pada tanaman cabai meningkatkan ketersediaan unsur hara pada tanah gambut. Ketersediaan unsur hara nitrogen, fosfor, kalium dan magnesium yang optimal bagi tanaman dapat meningkatkan pembentukan klorofil. Peningkatan klorofil akan 
meningkatkan aktifitas fotosintesis, sehingga menghasilkan fotosintat yang lebih banyak yang berhubungan dengan hasil umbi (Herlina dan Elsie, 2016).

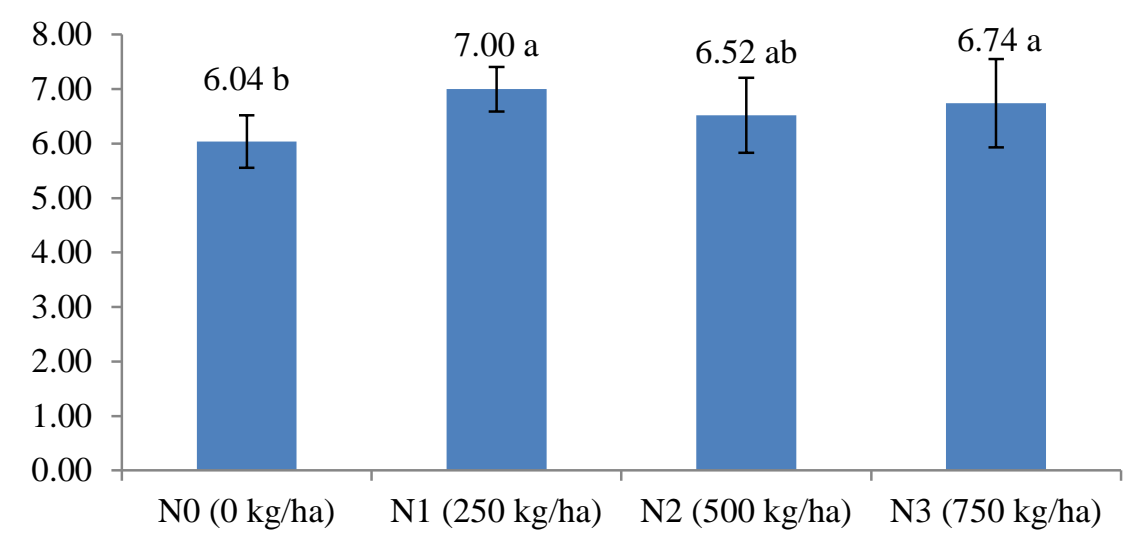

Gambar 1. Rata-rata jumlah umbi perrumpun tanaman bawang merah pada perlakuan pupuk NPK pada sistem tumpangsari dengan cabai di tanah gambut.

Pemupukan NPK lebih dari $250 \mathrm{~kg} / \mathrm{ha}$ tidak memberikan pengaruh nyata terhadap jumlah umbi per rumpun bawang merah pada system tumpangsari dengan cabai di tanah gambut. Hal ini menunjukkan bahwa dengan dosis NPK $250 \mathrm{~kg} / \mathrm{ha}$ pada system tumpangsari telah cukup untuk memenuhi kebutuhan tanaman bawang merah. Selain itu, pada penelitian ini semua plot mendapatkan pemupukan NPK dasar dengan dosis yang sama untuk tanaman bawang merah. Oleh karena itu, tanah gambut masih mengandung cukup hara dari pemupukan sebelumnya, sehingga peningkatan dosis pupuk NPK diatas $250 \mathrm{~kg} / \mathrm{ha}$ pada tanaman cabai tidak memberikan pengaruh nyata terhadap jumlah umbi per rumpun bawang merah.

\section{Produksi bawang merah}

Hasil uji $F$ pada analisis ragam menunjukkan bahwa perlakuan jarak tanam cabai merah dan pupuk NPK dalam sistem tumpangsari dengan bawang merah berpengaruh nyata terhadap produksi berat umbi basah dan kering per rumpun tanaman bawang merah. Rata-rata nilai peubah yang diamati dapat dilihat pada Tabel 2.

Tabel 2 menunjukkan bahwa produksi bawang merah yaitu berat umbi basah dan kering per rumpun yang ditumpangsarikan dengan cabai merah pada tanah gambut terlihat bahwa perlakuan jarak tanam cabai terlebar (70 $\mathrm{cm} \times 50 \mathrm{~cm}$ ) dengan dosis pemupukan NPK 750 $\mathrm{kg} / \mathrm{ha}$ (J3N3) memberikan hasil tertinggi.
Namun tidak berbeda nyata dengan jarak tanam rapat $(50 \mathrm{~cm} \times 50 \mathrm{~cm})$ dengan dosis pemupukan $500 \mathrm{~kg} / \mathrm{ha}$ (J1N2). Hal ini diduga pada system tumpangsari tanaman cabai dengan bawang merah pada tanah gambut, jarak tanam yang lebih rapat akan memberikan perkembangan perakaran yang lebih rapat antar kedua tanaman tersebut. Rapatnya perkembangan perakaran tersebut memungkinkan pupuk NPK yang diberikan terserap lebih banyak dibandingkan yang tercuci sehingga pemberian pupuk NPK lebih efisien.

Jarak tanam cabai yang semakin lebar mengakibatkan semakin rendah berat umbi per rumpun tanaman bawang merah. Hal ini karena jarak antara cabai dengan bawang yang semakin lebar memberikan ruang terbuka yang lebih lebar. Hal ini berhubungan dengan tanah gambut merupakan tanah yang kurang subur yang menyebabkan pertumbuhan akar tanaman juga terhambat. Oleh karena itu, jarak tanam yang lebar pada tanah gambut mengakibatkan kemampuan perakaran dalam menahan air dan unsur hara juga rendah. Selain itu, sifat tanah gambut yang berporositas tinggi sehingga saat panas akan terjadi evaporasi dan saat hujan unsur hara akan tercuci (leaching) (Nora dkk, 2016). Hal ini yang mengakibatkan unsur hara (pupuk NPK) yang diberikan banyak yang hilang, sehingga dengan dosis NPK tinggi (750 $\mathrm{kg} / \mathrm{ha}$ ) baru dapat mencukupi kebutuhan tanaman.

Dalam menentukan jarak tanam selain faktor jenis tanaman yang akan dibudidayakan, 
faktor lingkungan juga perlu diperhatikan seperti tanah. Pada penelitian ini tanah gambut yang digunakan. Seperti yang diketahui tanah gambut merupakan tanah memiliki tingkat kesuburan rendah. Penentuan jarak tanam pada daerah yang kurang subur akan berbeda dengan tanah yang subur. Yulfa (2017) menyatakan bahwa jarak tanam di tanah kurang subur lebih rapat dibandingkan tanah subur, begitu pula jarak tanam di lahan gambut lebih rapat dibandingkan di tanah mineral. Hal ini berkaitan dengan kemampuan tanah dalam menjerap air dan unsur hara. Berdasarkan pernyataan tersebut, hal ini yang menyebabkan jarak tanam yang lebih rapat $(50 \times 50 \mathrm{~cm})$ menghasilkan berat umbi basah dan kering per rumpun yang tidak berbeda nyata dengan jarak tanam lebar.

Tabel 2. Rata-rata produksi tanaman bawang merah pada perlakuan jarak tanam dan pupuk NPK dalam sistem tumpangsari cabai dengan bawang merah di tanah gambut

\begin{tabular}{|c|c|c|c|c|}
\hline \multirow[b]{2}{*}{ Jarak Tanam } & \multicolumn{4}{|c|}{ Pupuk NPK } \\
\hline & $\begin{array}{c}\mathrm{N} 0 \\
(0 \mathrm{~kg} / \mathrm{ha})\end{array}$ & $\begin{array}{c}\mathrm{N} 1 \\
(250 \mathrm{~kg} / \mathrm{ha})\end{array}$ & $\begin{array}{c}\mathrm{N} 2 \\
(500 \mathrm{~kg} / \mathrm{ha})\end{array}$ & $\begin{array}{c}\mathrm{N} 3 \\
(750 \mathrm{~kg} / \mathrm{ha})\end{array}$ \\
\hline \multicolumn{5}{|c|}{ Berat umbi basah per rumpun (g) } \\
\hline $\mathrm{J} 2(60 \mathrm{~cm} \times 50 \mathrm{~cm})$ & $17,21 \mathrm{~d}$ & $26,79 \mathrm{bc}$ & $26,68 \mathrm{bc}$ & $21,78 \mathrm{~cd}$ \\
\hline $\mathrm{J} 3(70 \mathrm{~cm} \times 50 \mathrm{~cm})$ & $22,37 \mathrm{~cd}$ & $23,84 \mathrm{c}$ & $22,47 \mathrm{c}$ & 34,59 a \\
\hline $\mathrm{KK}=12,15 \%$ & \multicolumn{4}{|c|}{ BNT $5 \%=5,19$} \\
\hline \multicolumn{5}{|c|}{ Berat umbi kering per rumpun (g) } \\
\hline $\mathrm{J} 1(50 \mathrm{~cm} \times 50 \mathrm{~cm})$ & $18,39 \mathrm{~cd}$ & $21,45 \mathrm{bcd}$ & $25,08 \mathrm{ab}$ & $23,37 \mathrm{~b}$ \\
\hline $\mathrm{J} 2(60 \mathrm{~cm} \times 50 \mathrm{~cm})$ & $13,32 \mathrm{e}$ & $21,20 \mathrm{bcd}$ & $21,76 \mathrm{bc}$ & $17,45 \mathrm{~d}$ \\
\hline $\mathrm{J} 3(70 \mathrm{~cm} \times 50 \mathrm{~cm})$ & $17,82 \mathrm{~cd}$ & $19,09 \mathrm{~cd}$ & $17,65 \mathrm{~d}$ & 28,43 a \\
\hline $\mathrm{KK}=12,10 \%$ & \multicolumn{4}{|c|}{ BNT $5 \%=4,10$} \\
\hline
\end{tabular}

Angka-angka pada baris dan kolom yang diikuti huruf kecil yang sama menunjukan tidak berbeda nyata menurut uji BNT $(\alpha=0.05)$.

\section{Pertumbuhan dan Produksi Tanaman Cabai Merah}

\section{Pertumbuhan Cabai Merah}

Hasil analisis ragam menunjukkan bahwa jarak tanam cabai dan pemberian pupuk NPK tidak berpengaruh nyata terhadap tinggi tanaman cabai merah Rata-rata tinggi tanaman cabai dapat dilihat pada Tabel 3.

Tabel 3. Rata-rata tinggi tanaman cabai merah pada perlakuan jarak tanam dan pupuk NPK dalam sistem tumpangsari cabai dengan bawang merah di tanah gambut

\begin{tabular}{lcccc}
\hline \multirow{2}{*}{ Jarak Tanam } & \multicolumn{4}{c}{ Pupuk NPK } \\
\cline { 2 - 5 } & $\begin{array}{c}\mathrm{N} 0 \\
(0 \mathrm{~kg} / \mathrm{ha})\end{array}$ & $\begin{array}{c}\mathrm{N} 1 \\
(250 \mathrm{~kg} / \mathrm{ha})\end{array}$ & $\begin{array}{c}\mathrm{N} 2 \\
(500 \mathrm{~kg} / \mathrm{ha})\end{array}$ & $\begin{array}{c}\mathrm{N} 3 \\
(750 \mathrm{~kg} / \mathrm{ha})\end{array}$ \\
\hline $\mathrm{J} 1(50 \mathrm{~cm} \times 50 \mathrm{~cm})$ & 60.17 & 59.00 & 53.67 & 51.00 \\
$\mathrm{~J} 2(60 \mathrm{~cm} \times 50 \mathrm{~cm})$ & 54.17 & 50.67 & 60.83 & 45.33 \\
$\mathrm{~J} 3(70 \mathrm{~cm} \times 50 \mathrm{~cm})$ & 49.67 & 61.50 & 48.50 & 56.50 \\
\hline
\end{tabular}

$\mathrm{KK}=15.89 \%$

Angka-angka pada baris dan kolom yang diikuti huruf kecil yang sama menunjukan tidak berbeda nyata menurut uji BNT $(\alpha=0.05)$.

Tabel 3 menunjukkan bahwa kombinasi perlakuan jarak tanam dan pupuk NPK memberikan tinggi tanaman yang cenderung sama pada setiap perlakuan. Hal ini diduga bahwa jarak tanam yang digunakan tidak terjadi 
kompetisi cahaya matahari dan unsur hara antara tanaman sejenis (cabai dengan cabai) maupun berbeda jenis (cabai dengan bawang) yang menyebabkan tinggi tanaman cabai cenderung sama. Hal ini didukung oleh pernyataan Gardner., dkk (1991) bahwa, pertumbuhan tanaman sangat di tentukan oleh intensitas, kualitas, dan lamanya penyinaran.

Tinggi tanaman cabai merah dari hasil penelitian $(49.67-61.50 \mathrm{~cm})$ jauh lebih rendah dari deskripsi yaitu 110-140 cm. Rendahnya pertumbuhan tanaman cabai berhubungan erat dengan kondisi lingkungan saat penelitian. Pada saat penelitian di lapangan musim kemarau sehingga tanaman cabai mudah terserang hama dan penyakit diantaranya adalah hama trips, kutu kebul dan kutu daun persik. Tanaman cabai terserang hama trips yang mengakibatkan keriting daun pada umur 4 MST, sehingga pertumbuhan tanaman cabai terhambat. Menurut Nurfalach (2010) pada musim kemarau tanaman cabai rentan terhadap serangan hama dan penyakit. Sherly dkk. (2010) menambahkan bahwa tanaman cabai yang terserang trips dan kutu daun akan menyebabkan daunnya menjadi keriput dan pertumbuhan tanaman menjadi terhambat (kerdil).

Selain itu, rendahnya pertumbuhan tanaman cabai pada penelitian ini diduga karena varietas tersebut belum adaptif pada tanah masam (gambut). Pada tanah masam faktor mendasar yang mengakibatkan pertumbuhan tanaman terhambat (kerdil) yaitu keracunan alumunium. Kosentrasi Al tinggi pada tanah asam dapat menghambat pertumbuhan beberapa spesies (Salisburry dan Ross, 1995). Beberapa pengaruh buruk keberadaan Al tersebut antara lain: terjadi gangguan penyerapan hara, bergabung dengan dinding sel, dan menghambat pembelahan sel. Tanaman yang mampu beradaptasi pada $\mathrm{Al}$ tinggi akan memiliki suatu mekanisme tertentu untuk menekan pengaruh buruk Al sehingga tidak menganggu serapan hara dan air (Sudrajat, 2010).

\section{Produksi cabai merah}

Hasil analisis ragam menunjukkan bahwa bahwa jarak tanam cabai dan pemberian pupuk NPK berpengaruh nyata terhadap jumlah buah pertanaman, bobot buah pertanaman dan bobot per buah. Rata-rata jumlah buah pertanaman, bobot buah pertanaman dan bobot per buah cabai dapat dilihat pada Tabel 4.
Berdasarkan data hasil produksi cabai merah (Tabel 4), hasil penelitian menunjukkan bahwa jumlah buah per tanaman dan bobot buah per tanaman cabai merah dalam sistem tumpangsari pada tanah gambut terlihat bahwa kombinasi perlakuan jarak tanam $60 \mathrm{~cm}$ x $50 \mathrm{~cm}$ (J2N2) dengan dosis pupuk NPK $500 \mathrm{~kg} / \mathrm{ha}$ memberikan hasil yang sama baiknya dengan kombinasi perlakuan jarak tanam $70 \mathrm{~cm}$ x $50 \mathrm{~cm}$ (J3N3) dengan dosis pupuk $750 \mathrm{~kg} / \mathrm{ha}$, serta perlakuan jarak tanam $50 \times 50 \mathrm{~cm}$ dengan dosis pupuk $250 \mathrm{~kg} / \mathrm{ha}$. Hal ini menunjukkan belum terjadinya persaingan dalam memanfaatkan ruang tumbuh terutama cahaya, sehingga jarak tanam yang lebih rapat dapat menghasilkan hasil tanaman yang relatif sama dengan jarak tanam yang lebih besar. Berdasarkan hal tersebut diduga ketersediaan unsur hara yang dibutuhkan oleh cabai merah tidak terganggu dengan keberadaan bawang merah di daerah perakarannya. Hal ini sependapat dengan pernyataan Surtinah, dkk (2017) yang menyatakan bahwa hasil jagung manis yang ditanam secara tumpangsari dengan kangkung tidak berbeda dengan hasil monokultur.

Selain itu, semakin rapat jarak tanam cabai, penggunaan pupuk NPK dapat dikurangi. Menurut Maulidi dan Mustamir (2012), jarak tanam yang rapat penyerapan unsur hara lebih efisien dari pada jarak tanam lebar hal ini dapat terlihat pada hasil produksi cabai merah. Pada penelitian ini, pengaturan jarak tanam yang lebih rapat $(50 \mathrm{~cm} \times 50 \mathrm{~cm})$ juga mampu menekan penggunaan pupuk NPK hingga 50\%. Hal ini juga sesuai dengan pernyataan Sapito, dkk (2013) yang menyatakan bahwa dengan pemberian pupuk anorganik $1 / 4$ dosis anjuran dapat meningkatkan pertumbuhan cabai di tanah gambut.

Namun bila diamati pada bobot per buah cabai, perlakuan jarak tanam $60 \mathrm{cmx} 50 \mathrm{~cm}$ dengan dosis pupuk NPK $500 \mathrm{~kg} / \mathrm{ha}(2.00 \mathrm{~g})$ dan jarak tanam $70 \mathrm{~cm} \times 50 \mathrm{~cm}$ dengan dosis pupuk NPK $750 \mathrm{~kg} / \mathrm{ha}(2.40 \mathrm{~g})$ menghasilkan buah yang nyata lebih kecil dibandingkan perlakuan jarak tanam $50 \mathrm{~cm}$ x $50 \mathrm{~cm}$ dengan dosis pupuk NPK $250 \mathrm{~kg} / \mathrm{ha}(2.79 \mathrm{~g})$. Hal ini menunjukkan bahwa perlakuan jarak tanam $50 \mathrm{~cm}$ x $50 \mathrm{~cm}$ dengan dosis pupuk NPK $250 \mathrm{~kg} / \mathrm{ha}$ menghasilkan buah yang memiliki kualitas umbi yang lebih tinggi. Maenurt Nora, dkk (2016) jarak tanam yang renggang dapat menghasilkan kualitas hasil yang lebih baik terutama pada 
lahan yang subur, namun untuk lahan marginal seperti gambut digunakan jarak tanam yang rapat sehingga diharapkan tanaman memberikan hasil dengan kuantitas dan kualitias yang tinggi.

Tabel 4. Produksi tanaman cabai merah pada sistem tumpangsari di tanah gambut

\begin{tabular}{|c|c|c|c|c|}
\hline \multirow[b]{2}{*}{ Jarak Tanam } & \multicolumn{4}{|c|}{ Pupuk NPK } \\
\hline & $\begin{array}{c}\text { N0 } \\
(0 \mathrm{~kg} / \mathrm{ha}) \\
\end{array}$ & $\begin{array}{c}\text { N1 } \\
(250 \mathrm{~kg} / \mathrm{ha})\end{array}$ & $\begin{array}{c}\mathrm{N} 2 \\
(500 \mathrm{~kg} / \mathrm{ha})\end{array}$ & $\begin{array}{c}\mathrm{N} 3 \\
(750 \mathrm{~kg} / \mathrm{ha}) \\
\end{array}$ \\
\hline \multicolumn{5}{|l|}{ Jumlah buah per tanaman * } \\
\hline $\mathrm{J} 1(50 \mathrm{~cm} \times 50 \mathrm{~cm})$ & $\begin{array}{l}5,17 b c \\
(27,00)\end{array}$ & $\begin{array}{l}5,44 \text { abc } \\
(30,00)\end{array}$ & $\begin{array}{l}4,06 \text { de } \\
(16,67)\end{array}$ & $\begin{array}{l}4,80 \mathrm{~cd} \\
(23,50)\end{array}$ \\
\hline $\mathrm{J} 2(60 \mathrm{~cm} \times 50 \mathrm{~cm})$ & $\begin{array}{l}5,13 \text { bc } \\
(26,33)\end{array}$ & $\begin{array}{l}6,08 \mathrm{ab} \\
(37,00)\end{array}$ & $\begin{array}{l}6,40 \mathrm{a} \\
(41,67)\end{array}$ & $\begin{array}{l}3,78 \mathrm{e} \\
(14,50)\end{array}$ \\
\hline $\mathrm{J} 3(70 \mathrm{~cm}$ x $50 \mathrm{~cm})$ & $\begin{array}{l}4,03 \mathrm{de} \\
(16,33) \\
\end{array}$ & $\begin{array}{l}5,20 \mathrm{bc} \\
(27,17) \\
\end{array}$ & $\begin{array}{l}3,84 \text { de } \\
(14,83) \\
\end{array}$ & $\begin{array}{l}6,29 \mathrm{a} \\
(39,83)\end{array}$ \\
\hline \multicolumn{5}{|l|}{$\mathrm{KK}=11.30 \% \quad$ BNT 5\%=0.97 } \\
\hline \multicolumn{5}{|l|}{ Bobot buah per tanaman $(\mathrm{g})^{*}$} \\
\hline $\mathrm{J} 1(50 \mathrm{~cm}$ x $50 \mathrm{~cm})$ & $\begin{array}{l}7,50 \mathrm{~b}-\mathrm{f} \\
(57,51)\end{array}$ & $\begin{array}{l}8,85 \mathrm{ab} \\
(79,87)\end{array}$ & $\begin{array}{l}6,78 \mathrm{def} \\
(46,39)\end{array}$ & $\begin{array}{l}6,90 \mathrm{c}-\mathrm{f} \\
(48,30)\end{array}$ \\
\hline $\mathrm{J} 2(60 \mathrm{~cm} \times 50 \mathrm{~cm})$ & $\begin{array}{l}7,58 \text { b-e } \\
(57,62)\end{array}$ & $\begin{array}{l}8,76 \mathrm{abc} \\
(76,83)\end{array}$ & $\begin{array}{l}9,11 \mathrm{ab} \\
(86,40)\end{array}$ & $\begin{array}{l}5,62 \mathrm{f} \\
(32,50)\end{array}$ \\
\hline $\mathrm{J} 3(70 \mathrm{~cm}$ x $50 \mathrm{~cm})$ & $\begin{array}{l}6,43 \text { ef } \\
(41,58) \\
\end{array}$ & $\begin{array}{l}8,57 \text { a-d } \\
(73,90)\end{array}$ & $\begin{array}{l}5,76 \text { ef } \\
(33,31) \\
\end{array}$ & $\begin{array}{l}9,75 \mathrm{a} \\
(95,97)\end{array}$ \\
\hline \multicolumn{5}{|l|}{$\mathrm{KK}=14.89 \% \quad$ BNT 5\%=1.91 } \\
\hline \multicolumn{5}{|l|}{ Bobot per buah $(\mathrm{g})$} \\
\hline $\mathrm{J} 1(50 \mathrm{~cm} \times 50 \mathrm{~cm})$ & $2,09 \mathrm{~d}$ & $2,66 \mathrm{ab}$ & $2,79 \mathrm{a}$ & $2,08 \mathrm{~d}$ \\
\hline $\mathrm{J} 2(60 \mathrm{~cm} \times 50 \mathrm{~cm})$ & $2,19 \mathrm{~cd}$ & $2,07 \mathrm{~d}$ & $2,00 \mathrm{~d}$ & $2,19 \mathrm{~cd}$ \\
\hline $\mathrm{J} 3(70 \mathrm{~cm} \times 50 \mathrm{~cm})$ & $2,55 \mathrm{abc}$ & $2,71 \mathrm{a}$ & $2,25 \mathrm{bcd}$ & 2,40 a-d \\
\hline
\end{tabular}

$\mathrm{KK}=11.58 \% \quad$ BNT 5\%=0.44

*Data di transformasi $\sqrt{x}$. Angka dalam kurung menunjukkan data asli.

Angka-angka pada baris dan kolom yang diikuti huruf kecil yang sama menunjukan tidak berbeda nyata menurut uji BNT $(\alpha=0.05)$.

Berdasarkan bobot buah per tanaman, potensi produksi cabai tertinggi pada penelitian ini yaitu 3.84 ton/ha. Hasil tersebut masih lebih rendah dibandingkan dengan potensi hasil cabai varietas Lado F1. Rendahnya produksi cabai merah yang dihasilkan pada penelitian ini diduga karena varietas yang digunakan belum adaptif untuk dibudidayakan di tanah gambut. Sleeper (1995) menyatakan komponen hasil seperti bobot per buah dan bobot buah total per tanaman merupakan karakter kuantitatif yang kompleks yang terekspresi secara fenotipe baik morfologi maupun fisiologi tanaman yang dipengaruhi oleh genetik dan lingkungan tempat tanaman tumbuh. Selain itu, dikarenakan penyakit keriting daun yang menyerang hingga $80 \%$ tanaman cabai, sehingga produksi yang didapatkan kehilangan hasil hingga $60 \%$. Sesuai dengan pernyataan Basri (2011) yang menyatakan bahwa virus kuning pada tanaman cabai dapat mengakibatkan kehilangan hasil 20$100 \%$.

\section{KESIMPULAN}

1. Perlakuan jarak tanam dan pemupukan NPK nyata meningkatkan tinggi tanaman, bobot basah per rumpun dan bobot kering per rumpun tanaman bawang merah. Pertumbuhan dan hasil terbaik diperoleh pada kombinasi perlakuan jarak tanam rapat $(50 \mathrm{~cm} \times 50 \mathrm{~cm})$ dengan pupuk NPK dosis $500 \mathrm{~kg} / \mathrm{ha}$.

2. Perlakuan jarak tanam dan pemupukan NPK nyata jumlah buah, berat buah per tanaman dan berat buah per buah tanaman cabai merah. Hasil terbaik diperoleh pada kombinasi perlakuan jarak tanam rapat (50 $\mathrm{cm} \times 50 \mathrm{~cm}$ ) dengan pupuk NPK dosis 250 $\mathrm{kg} / \mathrm{ha}$.

3. Pengaturan jarak tanam cabai pada perlakuan tumpangsari tanaman cabai dengan bawang merah dapat mengurangi penggunaan pupuk NPK pada tanaman cabai hingga $50 \%$. 


\section{SARAN}

Perlu penelitian lanjutan dengan menggunakan beberapa varietas tanaman cabai yang adaptif atau toleran pada tanah gambut.

\section{DAFTAR PUSTAKA}

Basri, AB. 2011. Pengendalian Penyakit Keriting Daun Cabai Merah. Serambi Pertanian BPTP NAD, 5(6): 1-2.

Gardner, F. P. R. B Pear dan F. L. Mitaheel. 1991. Fisiologi Tanaman Budidaya. Terjemahan Universitas Indonesia Press. Jakarta. 428 hal.

Herlina, N dan Elsie. 2016. Produksi Bawang Merah (Allium ascalonicum L.) dengan Pemberian Trichokompos Terformulasi dan Kalium di Lahan Gambut Rimbo Panjang Kabupaten Kampar, Riau. Jurnal Photon, 7(1): 57-64.

Jumin, H.B. 2010. Dasar-dasar Agronomi. Edisi Revisi. Rajawali Press. Jakarta.

Madkar, O. R. 2002. Pengaruh Aplikasi Herbisida terhadap Produktivitas Tanaman pada Sistem Tanaman Tunggal dan Tumpangsari. Skripsi. Universitas Padjajaran. Bandung.

Mauidzotussyarifah, N. Aini, N. Herlina. 2018. Optimalisasi Pemanfaatan dengan Pola Tumpangsari pada Tanaman Buncis (Phaseolus vulgaris L.) dan Tanaman Pakcoy (Brassica rapachinensis). Jurnal Produksi Tanaman, 6(2):246-251.

Maulidi dan E. Mustamir. 2012. Upaya Peningkatan Hasil Tanaman Nenas Di Lahan Gambut. Jurnal Perkebunan \& Lahan Tropika, Vol. 2, No. 2: 32-38

Nora, E., Murniati, dan Idwar. 2016. Pengaruh Jarak Tanam dan Pemberian Kompos TKKS terhadap Pertumbuhan dan Produksi Bawang Merah (Allium ascalonicum L.) di Antara Sawit di Lahan Gambut. Jom Faperta, 3(2):1-15

Nurfalach, R.D. 2010. Budidaya tanaman cabai merah (Capsicum annum L.) Di UPTD perbibitan tanaman hortikultura Desa Pakopen Kecamatan Bandungan Kabupaten semarang. Skripsi. Fakultas Pertanian. Universitas Sebelas Maret Surakarta. Surakarta
Ratri,C.H, R. Soelistyono dan N. Aini. 2015. Pengaruh Waktu Tanam Bawang Prei (Allium porum L.) Pada Sistem Tumpangsari Terhadap Pertumbuhan Dan Hasil Tanaman Jagung Manis (Zea mays saccharata). Jurnal Produksi Tanaman, 3(5): $406-412$

Sapito, A., Gusmawartati, A I. Amri. 2013. Pengaruh pupuk anorganik pada tanah gambut terhadap produksi cabai merah (Capsicum annum L). Jom Faperta.4(2): $1-8$

Sasli, I. 2011. Karakteristik Gambut Dengan Berbagai Bahan Amelioran Dan Pengaruhnya Terhadap Sifat Fisik Dan Kimia Guna Mendukung Produktivitas Lahan Gambut. Jurnal Agrovigor. 4(1) : 42-50.

Sherly, P., Ariarti., Yuni, R. Prasetyo. 2010. Budidaya dan Pascapanen Cabai Merah (Capsicum annuum L.) Badan Penelitian dan Pengembangan Pertanian Balai Pengkajian Teknologi Pertanian Jawa Tengah.Anggaran FEATI TA. Jawa Tengah.

Sudrajat, D. 2010. Identifikasi Karakter Morfofisiologi Kedelai Adaptif Lahan Masam. Jurnal Penelitian Pertanian Terapan. 10 (2): 103-110.

Surtinah, N. Susi, dan S.U. Lestari. 2016. Optimasi Lahan Dengan Sistem Tumpang Sari Jagung Manis (Zea Mays Saccharata, Sturt) Dan Kangkung Sutra (Ipomea reptans) di Pekanbaru. Jurnal Ilmiah Pertanian, 12(2):62-72

Sutriana, S. dan R Baharuddin. 2019. Uji Tingkat Kematangan Kompos Terhadap Produksi Tiga Varietas Bawang Merah (Allium Ascolanicuml) Pada Tanah Gambut. Jurnal Ilmiah Pertanian, 16 (1): 25-35.

Turmudi E. 2002. Kajian Pertumbuhan Dan Hasil Tanaman Dalam Sistem Tumpangsari Jagung Dengan Empat Kultivar Kedelai Pada Berbagai Waktu Tanam. Jurnal Ilmu-Ilmu Pertanian Indonesia, 4(2): 89-96. 